\title{
BIBECHANA
}

A Multidisciplinary Journal of Science, Technology and Mathematics

ISSN 2091-0762 (online)

Journal homepage: http://nepjol.info/index.php/BIBECHANA

\section{Antibiotic susceptibility pattern of resistant Escherichia Coli from poultry waste}

\author{
S. Shrestha \\ Central Department Of Biotechnology \\ E mail: smitabiotech01@gmail.com \\ Article history: Received 8 October, 2012; Accepted 16 November, 2012
}

\begin{abstract}
The study was conducted in Kathmandu valley to investigate the relationship between the use of antibiotic and the development of the resistant form of Escherichia coli (E.coli), which were isolated from faecal waste of poultry farm. Out of 30 samples investigated, 20 samples were found to be E.coli positive. It was further investigated that the resistance pattern for the isolates of E.coli from poultry farm was tetracycline (100\%), penicillin (100\%), erythromycin (100\%), amoxicillin (90\%) and chloramphenicol $(60 \%)$.
\end{abstract}

Keywords: Antibiotics; Resistance pattern; Tetracycline; Penicillin; Erythromycin

\section{Introduction}

Poultry farming is the practice of raising poultry, such as chickens, turkeys, ducks, and other fowl for the purpose of farming, meat or egg production. Nowadays, especially in poultry production antibiotics are widely used as growth promoter and in treatment of infectious disease [1]. The use of antibiotics in the poultry production industries, for the promotion of growth, largely contributes to the high resistance to antimicrobial agents in normal flora of poultry [2] and pathogenic microorganisms [3]. Besides this the antibiotics are used for the adjustment of intestinal flora, favoring useful bacteria while suppressing other bacterial population which enhances the use of antibiotics as growth promoter. Many contend that this puts humans at risk and bacterial strains develop stronger and stronger resistances [4,5].

These resistant microorganisms may act as possible source for the transfer of antimicrobial resistance to human pathogens. Plasmid and transposon mediated resistance is widely transmitted between different species and genera including human pathogens [6]. Antibiotics are used extensively to prevent or to treat microbial infections in human and veterinary medicine. Apart from their use in aquaculture, they are also employed to promote more rapid growth of livestock [7,8]. However, E.Coli is the causative agent of human intestinal disease which remains a major cause of morbidity and mortality worldwide. These occur primarily in the developing countries where the access to effective antibiotic therapy is limited. The increase in number of drug resistant strains has also complicated the management of disease caused by E.coli.

The emergence of resistance to antibiotic is a relevant matter worldwide, but the retrieval of antibiograms for E.Coli is severely delayed when phenotypic methods are used. Early identification of drug resistance 
and particularly multidrug resistant strain (MDR) is routine in developed low prevalence countries but the methods are currently unavailable and are too costly for resource poor nations like Nepal where the burden of disease is greatest. Data on the identification of antibiotic resistant E.Coli is crucial in order to permit timely administration of appropriate antibiotic schedule and could potentially improve the efficacy of Multidrug Resistant treatments.

\section{Materials and Methods}

\section{Sample Collection}

Faecal samples of poultry were collected from different poultry farms of Kathmandu.

\section{Bacterial isolation}

Specimens were cultured on McConkey and Eosin Methyl Blue (EMB) agar and the colonies suspected to be $E$. coli were identified by various biochemical tests. The list of biochemical tests are as follows

\section{Indole test}

In this a loopful of bacteria was inoculate in a media containing Kovac's reagent containing $\mathrm{N}$ Amyl Alcohol 75ml, Hydrochloric acid (conc.) $25 \mathrm{ml}$ and p-dimethylamine benzaldehyde $5 \mathrm{gm}$ and observed for color change.

\section{Methyl Red Test}

In this a loop of bacteria was inoculated in a test tube having Methyl Red Voges Proskaur(MRVP) broth containing buffered peptone $7 \mathrm{gm}$, dextrose $5 \mathrm{gm}$, dipotassium phosphate $5 \mathrm{gm}$ and $\mathrm{pH} 7.4$ and incubated for 24 to $48 \mathrm{hrs}$. Then methyl red was added for the color change

\section{Voges proskaur test}

In this a loop of bacteria were inoculated in a test tube having MRVP broth and incubated for 48 hours. Then 20 drops of barrits reagent containing solution A containing $5 \mathrm{gm}$ alpha nephthol in $100 \mathrm{ml} 95 \%$ ethanol and solution B containing $40 \mathrm{gm}$ potassium hydroxide in $100 \mathrm{ml}$ distilled water were added to the test tubes and change in the color was noted

\section{Citrate utilization test}

The bacteria were inoculated in the simmon citrate agar containing Ammonium Dihydrogen Phosphate $1 \mathrm{gm}$, dipotassium Chloride $1 \mathrm{gm}$, Sodium chloride $5 \mathrm{gm}$, Magnesium sulphate $0.2 \mathrm{gm}$, Sodium citrate $2 \mathrm{gm}$, Agar15gm, Bromothymol blue $.08 \mathrm{gm}$ and $\mathrm{pH} 6.8$ slant and incubated for 48 hours. It was then observed for any color change

\section{Triple Sugar Iron test (TSI test)}

In this the bacteria was inoculated in the TSI agar slant containing glucose $0.1 \mathrm{gm}$, sucrose $1 \mathrm{gm}$, lactose $1 \mathrm{gm}$ and distilled water $100 \mathrm{ml}$ and incubated for $24 \mathrm{hrs}$. Then the change in color was observed

\section{Hydrogen Sulphide Test}

In this a loopful of bacteria was inoculated in SIM media containing ammonium ferric citrate 0.2gm, casein peptone $20 \mathrm{gm}$, meat peptone $6.6 \mathrm{gm}$, sodium thiosulphate $0.2 \mathrm{gm}$, distilled water $1000 \mathrm{ml}$. The change in color was noted.

\section{Urease test}

In this the bacteria was inoculated in the urea agar containing Phenol red solution and incubated at $35^{\circ} \mathrm{c}$ for $24 \mathrm{hrs}$. The urease production was examined by observing change in color.

\section{Antibiotic Susceptibility Determination}

Antibiotic susceptibility was done by single disc diffusion method. The following antibiotic discs were applied on Mueller hinton media: Penicillin $(\mathrm{P} / 10 \mu \mathrm{g})$, chloramphenicol $(\mathrm{C} / 30 \mu \mathrm{g})$, Tetracycline(TE/30 $\mu \mathrm{g})$, Amoxicillin( $\mathrm{AMX} / 10 \mu \mathrm{g})$, Erythromycin(E/10 $\mu \mathrm{g})$. Interpretation was done according to the criteria recommended in the National Committee for clinical Laboratory Standards (NCCLS. 1993) 


\section{Results and Discussion}

After the samples were collected from Kathmandu valley and microorganism were isolated, various biochemical tests were performed. The results of which are shown below

\section{Table 1: showing different biochemical test}

\begin{tabular}{|l|l|l|l|l|l|l|l|}
\hline Organisms & Indole test & MR test & VP test & Citrate test & TSI(Slant/Broth) & $\mathrm{H}_{2}$ S test & Urease test \\
\hline E.coli & Positive & positive & Negative & Negative & $\begin{array}{l}\text { Yellow color / Yellow } \\
\text { color }\end{array}$ & Negative & Negative \\
\hline Shigella & Negative & Negative & Negative & Negative & Red color/Yellow color & Negative & Negative \\
\hline Salmonella & Negative & Positive & Negative & Negative & Red color/Yellow color & Positive & Negative \\
\hline Proteus & Positive & Positive & Negative & Negative & Red color/Yellow color & Positive & Positive \\
\hline
\end{tabular}

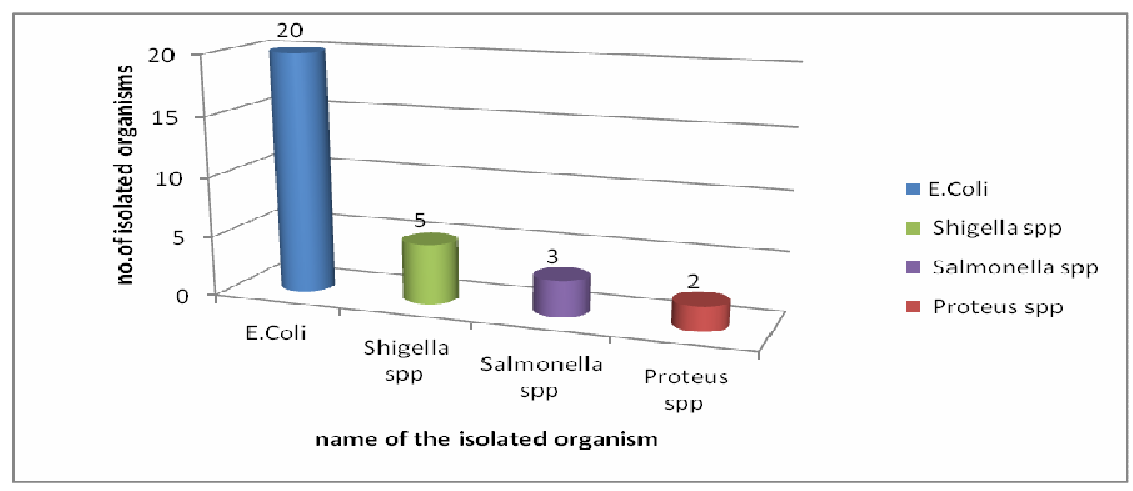

Fig 1 : Isolated Microorganism from Poultry.

From the above figure it was found that among 30, $20(66.66 \%)$ was identified as E.coli. 5(16.67\%) was identified as shigella spp. 3(10\%)was salmonella spp and 2(6.67\%)was proteus species.

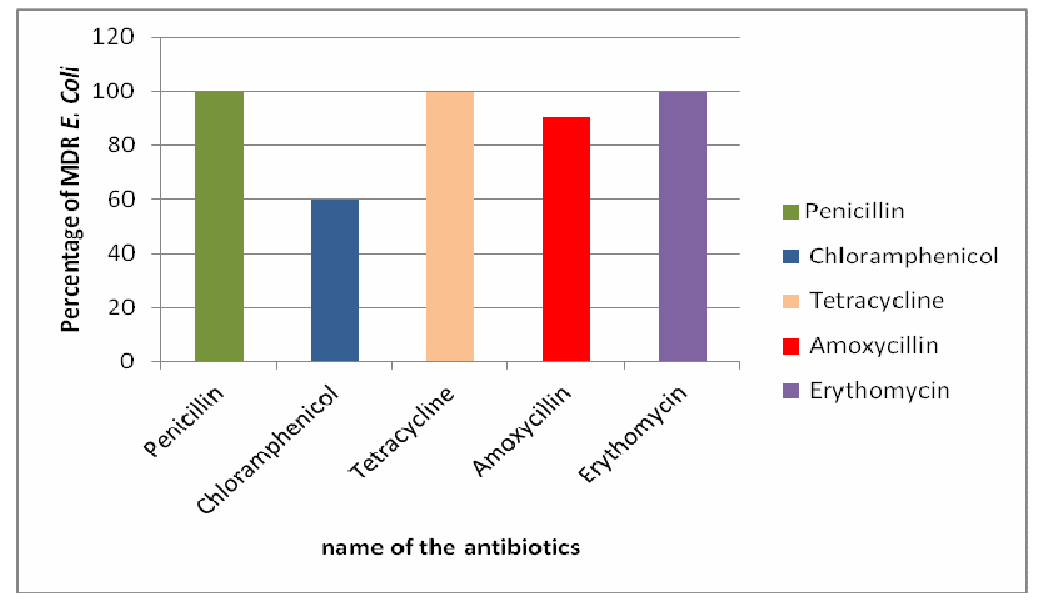

Fig 2 : Antibiotic Susceptibility Test.

From the above figure it was found that all the isolate were resistant to Penicillin(100\%), Chloramphenicol(60\%), Tetracycline (100\%), Amoxycillin(90\%) and Erythromycin(100\%). Analysis of the treatment history collected from the poultry farm showed that they used antibiotics mainly for 
treatment purpose. The resistance pattern of 20 isolates of E.coli isolated from poultry wastes clearly demonstrates the high resistance rate to all of the above tested antibiotics.

The increased antimicrobial resistance in bacteria especially pathogens, has received worldwide attention. The increasing failure of therapeutic intervention pushed the World Health Organization (WHO) to publish the "Global strategy for containment of antimicrobial resistance" in 2001[9]. This strategy was intended to minimize the increase of resistant bacterial strains while maintaining the effectiveness of the antibiotics already in use.

During recent years poultry industry has expanded very rapidly in Nepal and antibiotic resistance has emerged as one of the most severe problem having adverse effects on human health through their faecal waste and consuming their products. This has highlighted the need for taking extensive control measures to save the industry as well as humans. Worldwide data show that there is increasing resistance among urinary tract pathogens to conventional drugs especially with various strains of E.Coli [10]. Although new antibiotics are being developed eg. Glycylgycines [11] the level of antimicrobial resistance is not decreasing and it seems that development of resistance keeps pace with the development of new antibiotics.

Risk management of antimicrobial resistance is heavily biased towards banning the misuse of antibiotics [12]. It is also generally accepted that the high and often inappropriate use of antimicrobials and disinfectants, in both the humans and animals, is the main driver of resistance [13].

Increasingly, multiresistant bacteria are being detected in environmental compartments with a high bacterial density [14]. The source of these bacteria as well as the transfer of resistance between different environment compartments, require further investigation and should be included in risk analysis. The results obtained from this research will help in monitoring antimicrobial resistance in environment where there is a high usage antibiotic. However, healthy and preferably antimicrobial naive populations should also be monitored, to have a better overview of the spread of antimicrobial activity in a population. Besides this, it will also give a baseline data about the antibiotic susceptibility pattern of some commonly used antibiotics used in poultry farm.

\section{References}

[1] W. Wolfgang, Medical Consequences of Antibiotic Use in Agriculture science, 279 (1998) $996-997$.

[2] B.J. Allan, W. van-den-hurk and A.A. Potter, Characterization of Escherichia coli isolates from cases of avian colibacillosis, Canadian journal of veterinary research, 57 (1993) 145-151.

[3] A. Amara, Z. Ziani and K. Bouzoubaa, Antibiotic resistance of Escherichia coli strains isolated in Morrocco from chickens with colibacillosis, Veterinary microbiology, 43 (1995) 29-51.

[4] A.L. Aronson, Potential impact of the use of antimicrobial drug in farm animal on public health presented at the meeting on pharmacology in the animal health sector, Colorado state university Fort Collins (1975).

[5] D.G. White, C. Hudson, J.J. Maurer, S. Ayers, M. D. Lee, L. Bolton, T. Foley and J. Sherwood. Characterization of chloramphenicol and Florphenicol resistance Eschericia coli associated with bovine diarrhea, Journal of Clinical Microbiolgy, 38 (2000) 4593-4598.

[6] J. Davis, Inactivation of antibiotics and the dissemination of resistance genes, Science, 264 (1994) $375-382$.

[7] R.J. Wise, K.J. Towner, C.A. Webster, R.C. Slack and T.O. Jones, Time to ball all antibiotics as animal growth promoting agents, Lancet, 348 (1996) 619

[8] K. Kummerer, Resistance in the environment. Journal of Antimicrobial Chemotherapy, 54 (2004) 311-320.

[9] I.K. Okele, K.P. Klugman, Z.A. Bhutta, A.G. Duse, P.Jenkins, T.F. O’Brian, A. PablosMendez, R. Laxminarayan, Antimicrobial resistance in developing countries, Part(II) : strategies for containment, The lancet Infectious Diseases, 5 (2005) 568-580.

[10] A.E. Van den Bogaard, N. London, C. Driessen and E.E. Stobberingh, Antibiotic resistance of faecal Escherichia coli in poultry farmers and poultry slaughterers, Journal of Antimicrobial Chemotherapy, 47 (2001) 763-771. 
S. Shrestha / BIBECHANA 9 (2013) 136-140: BMHSS, p.140 (Online Publication: Nov., 2012)

[11] I. Chopra, Glycyclines : Third generation tetracycline antibiotics, Current opinion in Pharmacology, 1 (2001) 464-469.

[12] C. Grugel, Meeting report : First National scientific symposium "Risk management for limitation of antibiotic resistance", International Journal of Microbiology, 296 (2006) 1-3.

[13] WHO, Global strategy for containment of Antimicrobial resistance, World health organization Geneva Switzerland, (2001).

[14] D. Berry, X. Chunwu, L. Raskin, Microbial ecology of drinking water distribution systems, Current Opinions in Biotechnology, 17 (2006) 297-302. 